\title{
Impact of the marine atmospheric boundary layer conditions on VSLS abundances in the eastern tropical and subtropical North Atlantic Ocean
}

\author{
S. Fuhlbrügge ${ }^{1}$, K. Krüger ${ }^{1}$, B. Quack ${ }^{1}$, E. Atlas ${ }^{2}$, H. Hepach ${ }^{1}$, and F. Ziska ${ }^{1}$ \\ ${ }^{1}$ GEOMAR Helmholtz-Zentrum für Ozeanforschung Kiel, Kiel, Germany \\ ${ }^{2}$ Rosenstiel School for Marine and Atmospheric Sciences, Miami, Florida, USA
}

Correspondence to: K. Krüger (kkrueger@geomar.de)

Received: 20 November 2012 - Published in Atmos. Chem. Phys. Discuss.: 5 December 2012

Revised: 13 May 2013 - Accepted: 30 May 2013 - Published: 4 July 2013

\begin{abstract}
During the DRIVE (Diurnal and Regional Variability of Halogen Emissions) ship campaign we investigated the variability of the halogenated very short-lived substances (VSLS) bromoform $\left(\mathrm{CHBr}_{3}\right)$, dibromomethane $\left(\mathrm{CH}_{2} \mathrm{Br}_{2}\right)$ and methyl iodide $\left(\mathrm{CH}_{3} \mathrm{I}\right)$ in the marine atmospheric boundary layer in the eastern tropical and subtropical North Atlantic Ocean during May/June 2010. The highest VSLS mixing ratios were found near the Mauritanian coast and close to Lisbon (Portugal). With backward trajectories we identified predominantly air masses from the open North Atlantic with some coastal influence in the Mauritanian upwelling area, due to the prevailing NW winds. The maximum VSLS mixing ratios above the Mauritanian upwelling were $8.92 \mathrm{ppt}$ for bromoform, $3.14 \mathrm{ppt}$ for dibromomethane and $3.29 \mathrm{ppt}$ for methyl iodide, with an observed maximum range of the daily mean up to $50 \%$ for bromoform, $26 \%$ for dibromomethane and $56 \%$ for methyl iodide. The influence of various meteorological parameters - such as wind, surface air pressure, surface air and surface water temperature, humidity and marine atmospheric boundary layer (MABL) height - on VSLS concentrations and fluxes was investigated. The strongest relationship was found between the MABL height and bromoform, dibromomethane and methyl iodide abundances. Lowest MABL heights above the Mauritanian upwelling area coincide with highest VSLS mixing ratios and vice versa above the open ocean. Significant high anticorrelations confirm this relationship for the whole cruise. We conclude that especially above oceanic upwelling systems, in addition to sea-air fluxes, MABL height variations can influence atmospheric VSLS mixing ratios, occasionally
\end{abstract}

leading to elevated atmospheric abundances. This may add to the postulated missing VSLS sources in the Mauritanian upwelling region (Quack et al., 2007).

\section{Introduction}

Natural halogenated very short-lived substances (VSLS) contribute significantly to the halogen content of the troposphere and lower stratosphere (WMO, 2011). On-going environmental changes such as increases in seawater temperature and nutrient supply, as well as decreasing $\mathrm{pH}$, are expected to influence VSLS production in the ocean. Thus, the oceanic emissions of VSLS might change in the future and, in connection with an altering efficiency of the atmospheric upward transport, might lead to significant future changes of the halogen budget of the troposphere/lower stratosphere (Kloster et al., 2007; Pyle et al., 2007; Dessens et al., 2009; Schmittner et al., 2008; Montzka and Reimann, 2011), as well as changes to the tropospheric oxidation capacity (Hossaini et al., 2012). Within the group of brominated VSLS, bromoform $\left(\mathrm{CHBr}_{3}\right)$ and dibromomethane $\left(\mathrm{CH}_{2} \mathrm{Br}_{2}\right)$ are the largest natural sources for bromine in the troposphere and stratosphere. In combination with iodine compounds (i.e. methyl iodide, $\mathrm{CH}_{3} \mathrm{I}$ ), they can alter tropospheric oxidation processes, including ozone depletion (Read et al., 2008). The VSLS have comparably short tropospheric lifetimes (days to months); however, they can be rapidly transported by deep convection, especially in the tropics, to the upper troposphere and lower stratosphere and contribute to ozone depletion 
there (Warwick et al., 2006; WMO, 2007, 2011; Tegtmeier et al., 2012, 2013). Previous studies have reported distinctive halocarbon emissions in tropical coastal and shelf water regions due to high biological productivity, i.e. by macro algae, seaweed and phytoplankton (Gschwend et al., 1985; Manley and Dastoor, 1988; Sturges et al., 1992; Moore and Tokarczyk, 1993; Carpenter and Liss, 2000; Quack et al., 2007). Elevated mixing ratios of the compounds have been found within the marine atmospheric boundary layer (MABL) around the Cape Verde Islands with a mean (range) for $\mathrm{CHBr}_{3}$ of 8 (2.0-43.7) ppt, $\mathrm{CH}_{2} \mathrm{Br}_{2}$ of $2(0.7-8.8) \mathrm{ppt}$ and $\mathrm{CH}_{3} \mathrm{I}$ of 3 (0.5-31.4) ppt (O'Brien et al., 2009) and in the area of the Mauritanian upwelling with a mean (range) of $\mathrm{CHBr}_{3}$ around 6 (3-12) ppt (Carpenter et al., 2007; Quack et al., 2007) and $\mathrm{CH}_{2} \mathrm{Br}_{2}$ of $2.4(1.75-3.44)$ ppt by Quack et al. (2007). These mean mixing ratios from the tropical Atlantic Ocean agree well with other tropical oceanic areas (e.g. Atlas et al., 1993; Butler et al., 2007). Quack et al. (2004) suggested regionally enhanced biogenic production in the water column of the Mauritanian upwelling and a high sea-to-air flux of VSLS to be responsible for elevated tropospheric VSLS mixing ratios in this region. However, Carpenter et al. (2007) and Quack et al. (2007) both pointed out that the marine boundary layer height, besides additional potential coastal sources, may affect the tropospheric VSLS mixing ratios as well. The theory of warm offshore air flowing over cool water and creating a stable internal boundary layer, as suggested by Garratt (1990), applies well in the area of the cold Mauritanian upwelling. Here, the sea surface roughness and near surface turbulence reduce each other over the water, while the flow leads to a collapse of turbulence and a very stable stratification of the lowermost atmosphere, as was observed by Vickers et al. (2001) at the coast of the United States and modelled by Skyllingstad et al. (2005).

In this study, we present first results from the DRIVE (Diurnal and Regional Variability of Halogen Emissions) ship campaign during May/June 2010, comprising highresolution meteorological and VSLS measurements. We investigate the meteorological constraints on the VSLS abundances and whether the cold waters upwelled along the Mauritanian coast have a verifiable influence on the atmospheric boundary layer height and therefore on the mixing of air within the lowermost troposphere. The accompanying study by Hepach et al. (2013) investigates the VSLS sources in the ocean and the sea-to-air fluxes in detail.

This paper begins with a short overview of the meteorological conditions during the DRIVE cruise, followed by a data and method description (Sect. 2.1). In Sect. 3 we present results from the meteorological and VSLS measurements and the influence of meteorology and MABL height on the VSLS mixing ratios and emissions. Finally, a summary is given in Sect. 4.

\section{Data and methods}

\subsection{Cruise overview}

During May/June 2010 the DRIVE (P399/2-3) campaign examined the formation and emission of halocarbons and reactive inorganic halogen compounds in the eastern tropical and subtropical North Atlantic Ocean (Bange et al., 2011) as part of the SOPRAN (Surface Ocean Processes in the Anthropocene: www.sopran.pangaea.de) project. The main objectives are to investigate the diurnal and regional variability of marine short-lived substances, as well as oceanic influences on the atmosphere.

The ship expedition was carried out on board the German research vessel (R/V) Poseidon. The cruise itself was split into two legs: P399/2 (31 May-17 June 2010) from Las Palmas to Las Palmas and P399/3 (19-24 June 2010) from Las Palmas to Vigo, Spain. For diurnal observations, hourly VSLS measurements were performed at six $24 \mathrm{~h}$ stations during leg P399/2. Positions and times of the $24 \mathrm{~h}$ stations are given in Table 1 . The location of the $24 \mathrm{~h}$ stations were chosen to cover the nutrient-rich coastal upwelling region near the Mauritanian coast as well as the nutrient-poor regions near the Cape Verde Islands. In addition, 21 atmospheric VSLS samples were taken during the return from the last station in the Mauritanian upwelling region to Las Palmas (Gran Canaria). During the transit leg P399/3, an additional 20 atmospheric air samples were taken. All VSLS measurements were also integrated into the HalOcAt database used for the Ziska et al. (2013) climatology.

\subsection{Meteorology and MABL height}

Meteorological data have been collected by the automatic on-board weather station of the German Weather Service (DWD): air and water temperatures, wind speed and direction, humidity and air pressure were recorded once per second and are averaged to $10 \mathrm{~min}$ means for our analysis. GRAW DFM-06 radiosondes (http://www.graw. de) were launched from the working deck of R/V Poseidon at about $3 \mathrm{~m}$ above sea level during the cruise to profile the atmospheric composition of air temperature (resolution: $0.1{ }^{\circ} \mathrm{C}$; accuracy: $<0.2^{\circ} \mathrm{C}$ ), relative humidity (resolution: $1 \%$; accuracy: $<5 \%$ ), and wind (wind speed accuracy: $<0.2 \mathrm{~m} \mathrm{~s}^{-1}$; horizontal position accuracy: $<5 \mathrm{~m}$ ) (http://www.gematronik.com/fileadmin/media/pdf/ GRAW-Brochure_V01.30_en.pdf) from the sea level up to the middle stratosphere ( $\sim 30 \mathrm{~km}$ altitude). At the $24 \mathrm{~h}$ stations, the launch frequency was increased from one radiosonde per day at 12:00 UTC to four per day at 00:00, 06:00, 12:00 and 18:00 UTC, amounting to 41 launches for the whole cruise.

The atmospheric boundary layer height is determined using the approaches summarized by Seibert et al. (2000). These methods include practical and theoretical 
Table 1. $24 \mathrm{~h}$ stations: position and date.

\begin{tabular}{cll}
\hline 24 h station & Position & Date/Time \\
\hline 1st & $17.6^{\circ} \mathrm{N}, 24.0^{\circ} \mathrm{W}$ & 3 June (23:00 UTC)-4 June 2010 (22:00 UTC) \\
2nd & $18.0^{\circ} \mathrm{N}, 21.0^{\circ} \mathrm{W}$ & 6 June (19:00 UTC)-7 June 2010 (17:00 UTC) \\
3th & $18.0^{\circ} \mathrm{N}, 18.0^{\circ} \mathrm{W}$ & 8 June (18:00 UTC)-9 June 2010 (17:00 UTC) \\
4th & $18.5^{\circ} \mathrm{N}, 16.5^{\circ} \mathrm{W}$ & 10 June (12:00 UTC)-11 June 2010 (11:00 UTC) \\
5th & $19.0^{\circ} \mathrm{N}, 16.5^{\circ} \mathrm{W}$ & 11 June (16:00 UTC)-12 June 2010 (15:00 UTC) \\
6th & $20.0^{\circ} \mathrm{N}, 17.25^{\circ} \mathrm{W}$ & 13 June (04:00 UTC)-14 June 2010 (03:00 UTC) \\
\hline
\end{tabular}

determinations from radiosoundings. The vertical extension of the boundary layer is in general limited aloft by a temperature inversion or a stable layer, or by a significant reduction in air moisture. Two general types of boundary layers exist, the convective boundary layer $(\mathrm{CBL})$, whose stable layer is found between the lower $100 \mathrm{~m}$ of the atmosphere and about $3 \mathrm{~km}$ height, and the stable boundary layer (SBL), characterized by a surface inversion. In the case of a CBL, it is recommended to take the height of the base of the inversion, increased by half of the inversion layer depth (Stull, 1988). For a SBL we assume the absence of turbulence and vertical mixing (Garratt, 1990) and further declare that the boundary layer stays close to the surface. According to this, we subjectively determined the height of the boundary layer in our study from the temperature and humidity profiles, and additionally from the bulk Richardson number of the following equation (Troen and Mahrt, 1986; Vogelezang and Holtslag, 1996):

$R i_{\mathrm{B}}=\frac{g z\left(\theta_{z}-\theta_{s}\right)}{\theta_{s}\left(u^{2}+v^{2}\right)}$.

The quantities $g$ and $z$ are the gravitation acceleration and the geometric height. $\theta_{z} \theta_{z}$ and $\theta_{\mathrm{s}} \theta_{\mathrm{s}}$ are the virtual potential temperature at the height $z$ and at the surface, and $u$ and $v$ are the zonal and meridional wind components. The virtual potential temperature can be regarded as a stability criterion for the atmosphere, considering the air moisture. It is constant with height for neutral conditions, increases for stable conditions and decreases if the air is statically unstable. To identify the boundary layer height theoretically, a fixed critical bulk Richardson number of $R i_{\mathrm{c}}=0.25$ is chosen as a threshold, following Sorensen (1998), where $R i_{\mathrm{B}} \geq R i_{\mathrm{c}}$. Due to missing wind data in the lowermost atmosphere during a number of radiosonde launches (failure of GPS sensor), we were not always able to determine $R i_{\mathrm{B}}$ for the lower boundary layer. Therefore we use the subjectively determined boundary layer height for our investigations and calculate $R i_{\mathrm{B}}$ to confirm our determined MABL height.

\subsection{Air mass origin}

For the analysis of the air mass origin, HYSPLIT trajectories (http://ready.arl.noaa.gov/HYSPLIT.php), based on NCEP/NCAR Reanalysis 1 (NNR), were calculated online.
The NNR is a first-generation reanalysis from 1948 to the present and has a horizontal resolution of $208 \mathrm{~km}$ (T62) and 28 vertical levels (L28) with a model top at about $3 \mathrm{hPa}$. The data are globally distributed on a $2.5^{\circ}$ latitude $\times 2.5^{\circ}$ longitude Gaussian grid with a total of $144 \times 73$ grid points (Kalnay et al., 1996; Kistler et al., 2001).

\subsection{VSLS measurements}

A total of 187 air samples were taken on the monkey deck of R/V Poseidon, about $10 \mathrm{~m}$ above sea level. The air was pressurized up to 2 standard atmospheres in pre-cleaned stainless steel canisters, each with a volume of $2.6 \mathrm{~L}$. The canisters were analysed within three months after the expedition at the Rosenstiel School for Marine and Atmospheric Sciences (RSMAS, Miami, Florida). The stability of the atmospheric samples has been demonstrated during more than 10 years of work with stainless steel canisters. The compounds reported here are typically stable for at least 6 months or more. The precision is estimated as an uncertainty of approximately $5 \%$, obtained from the standard variability during analysis and from examination of multiple samples within the same air mass. The analysis of the gases is performed with gas chromatography/mass spectrometry (GC/MS), while the calibration gases are standardized by gas chromatography with an atomic emission detector (AED) (Schauffler et al., 1999), and the entire standardization procedure was additionally adjusted to the NOAA scale in order to have better comparability to the NOAA measurements at surface stations. The preparation of standard gases is described in Montzka et al. (2003).

Our study concentrates on the atmospheric abundances of three VSLS: methyl iodide with a lifetime of $\sim 4$ days (Solomon et al., 1994), bromoform of $\sim 26$ days (Ko et al., 2003) and dibromomethane of $\sim 120$ days (Ko et al., 2003).

Samples for dissolved halocarbons in sea water were taken from the continuously working pump from the ship's moon pool at a depth of $5 \mathrm{~m}$ on a nearly hourly basis at every $24 \mathrm{~h}$ station. A purge and trap system attached to a gas chromatograph with mass spectrometric detection in single-ion mode was used for analysis of the samples with a precision within $10 \%$ determined from duplicates (Hepach et al., 2013). 


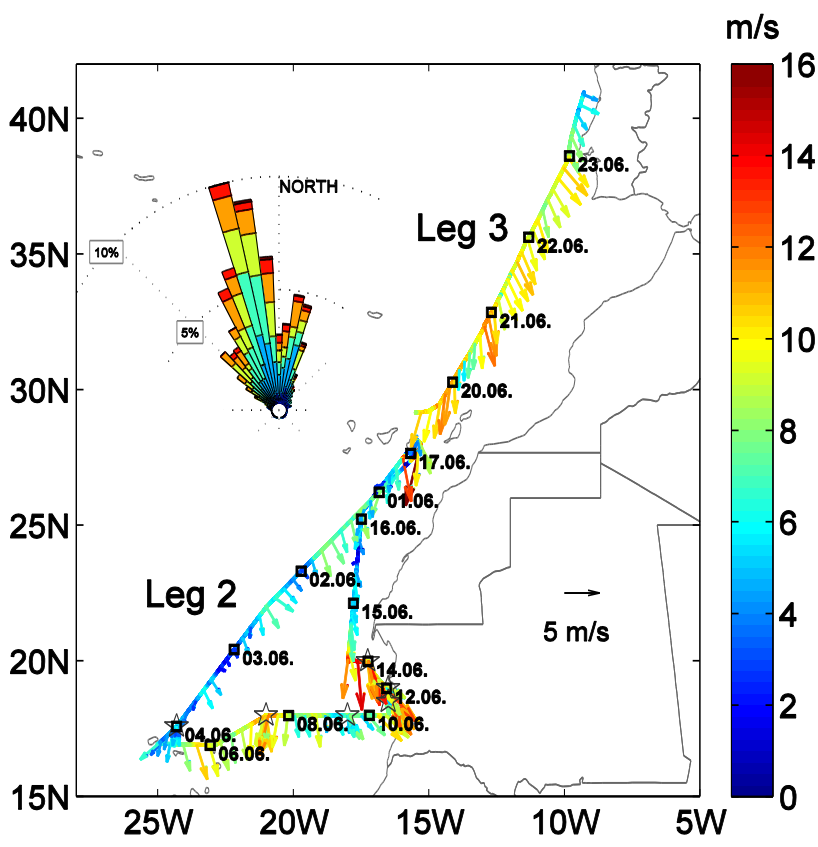

Fig. 1. DRIVE cruise track. In addition, the 3-hourly wind speed $\left[\mathrm{m} \mathrm{s}^{-1}\right]$, direction (10 min averages) and windrose for the whole cruise are shown.

\subsection{Sea-to-air flux calculations}

Sea-to-air fluxes $(F)$ of methyl iodide, dibromomethane and bromoform were calculated with the air-sea gas transfer coefficient $k_{w}$ and the air-sea concentration gradient $\Delta c$ (Hepach et al., 2013):

$F=k_{w} \cdot \Delta c$

The parameterization of Nightingale et al. (2000), based on instantaneous wind speeds (10 min averages) and temperature-dependent Schmidt numbers according to Quack and Wallace (2003), was applied to determine $k_{w} . \Delta c$ was calculated from the simultaneous water and air measurements at the $24 \mathrm{~h}$ stations.

\section{Results}

\subsection{Meteorology}

The cruise was mainly exposed to moderate weather conditions. Contrary to the climatological wind direction of northeasterly trade winds in the subtropics and westerlies north of $30^{\circ} \mathrm{N}$ during May/June, the mean absolute wind direction was NNW (Fig. 1) with a mean direction of $349^{\circ}$ during leg 2 and $344^{\circ}$ during leg 3 . This caused a predominant influence of air masses with marine background conditions coming from the open North Atlantic Ocean. The mean wind speed during the whole cruise was moderate to fresh for both legs, with $7.4 \mathrm{~m} \mathrm{~s}^{-1} \pm 2.9 \mathrm{~m} \mathrm{~s}^{-1}$ during leg 2

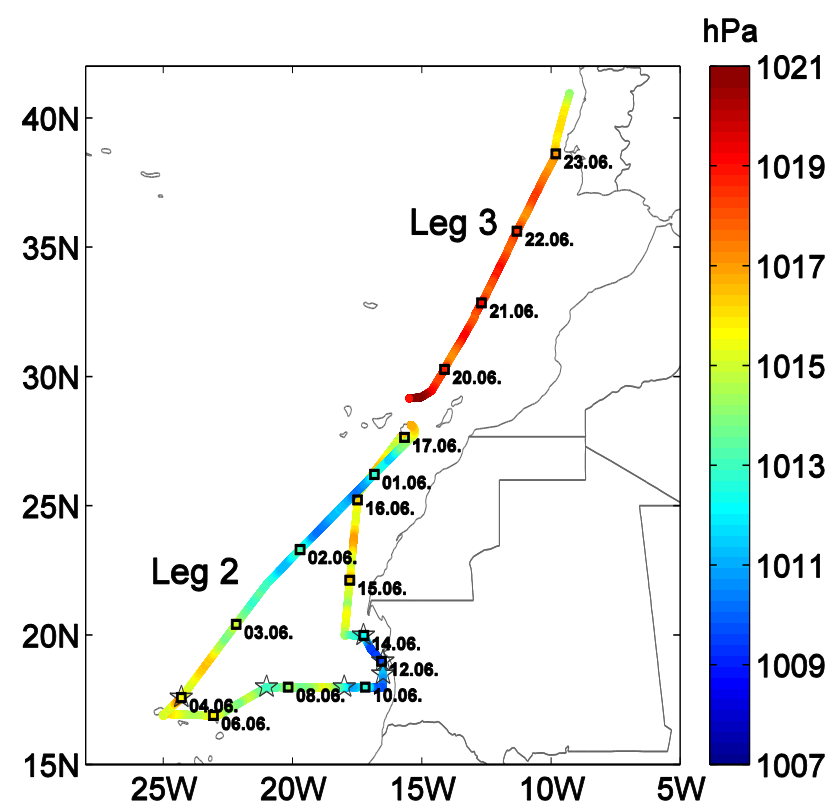

Fig. 2. 10 min average measurements of air pressure [hPa]. The stars indicate position and time of the diurnal stations.

and $9.3 \mathrm{~m} \mathrm{~s}^{-1} \pm 1.6 \mathrm{~m} \mathrm{~s}^{-1}$ during leg 3 . The total air pressure difference of $13.4 \mathrm{hPa}$ also reflects the moderate and steady weather conditions during the whole cruise with a minimum of $1007.6 \mathrm{hPa}$ on 11 June 2010 close to the Mauritanian coast and a maximum air pressure of $1021 \mathrm{hPa}$ at the beginning of leg 3 on 19 June 2010 close to the Canary Islands (Fig. 2). In addition, typical tropical diurnal variations up to $4 \mathrm{hPa}$ (see also Krüger and Quack, 2012) due to atmospheric tides were observed in this study. The time series of $10 \mathrm{~min}$ average measured surface air temperature $\left(T_{\mathrm{SAT}}\right)$, sea surface temperatures $\left(T_{\mathrm{SST}}\right)$ and the difference $\Delta T\left(T_{\mathrm{SAT}}-T_{\mathrm{SST}}\right)$ are shown in Fig. 3. The temperature difference is related to the heat flux between atmosphere and ocean and indicates suppressing of convection, turbulence and therefore mixing within the boundary layer for a positive temperature difference (positive heat flux) and enhanced mixing for negative heat flux. As the ship cruise started to the south, the air and water temperatures increased until the maximum air temperature of $25.8^{\circ} \mathrm{C}$ was recorded directly after the stop at Mindelo (Cape Verde Islands). On 11 June 2010, right after the 4th $24 \mathrm{~h}$ station, the ship reached the Mauritanian upwelling region at $18.75^{\circ} \mathrm{N}$, $16.5^{\circ} \mathrm{W}$. This is noticeable from the abrupt decrease in the water temperature and connected to an increase of the heat flux from the atmosphere to the ocean. After one day, the air temperature also drops, until $T_{\mathrm{SAT}}$ and $T_{\mathrm{SST}}$ stabilize between $18^{\circ} \mathrm{C}$ and $20^{\circ} \mathrm{C}$ (station 5). On 14 June 2010, after the ship has left the last $24 \mathrm{~h}$ station, the water temperature increases to about $23.5^{\circ} \mathrm{C}$. This increase coincides with a wind speed maximum of about $16 \mathrm{~m} \mathrm{~s}^{-1}$ from the north, indicating transport of water masses from outside the Mauritanian upwelling 


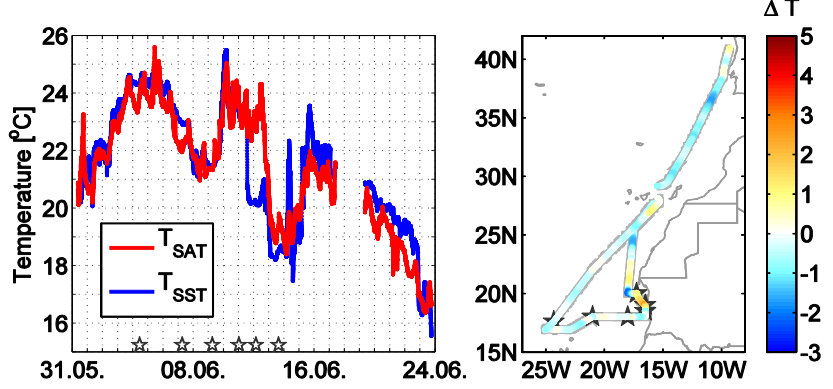

Fig. 3. Left: $10 \mathrm{~min}$ average measurements of $T_{\mathrm{SAT}}$ and $T_{\mathrm{SST}}\left[{ }^{\circ} \mathrm{C}\right]$. The stars indicate position and time of the diurnal stations. Right: the temperature gradient is given in $[\mathrm{K}]$.

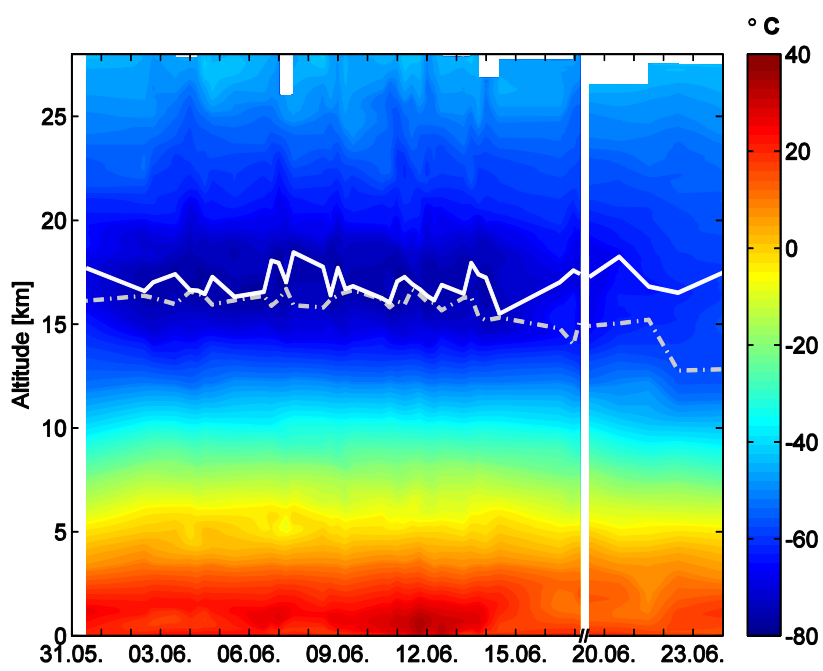

Fig. 4. Air temperature cross sections $\left[{ }^{\circ} \mathrm{C}\right]$ from radiosoundings for the whole cruise. Cold point tropopause and lapse rate tropopause are marked by the continuous and the dash-dotted lines, respectively. The measurement gap between leg 2 and 3 is shortened.

towards the ship, until the water temperature drops again to about $18^{\circ} \mathrm{C}$. On 15 June 2010 the ship left the Mauritanian upwelling region, indicated by increasing air and water temperatures until both decreased again while heading northward. A sudden decrease of the water temperature is also observed from 23 to 24 June 2010, as the ship enters the Iberian upwelling (Relvas and Barton, 2002).

\subsubsection{Marine atmospheric boundary layer}

In the following, we use the radiosonde measurements to analyse the state of the lower atmosphere. Profiles of air temperature along the cruise track are shown in Fig. 4. Lowest temperatures of $-80^{\circ} \mathrm{C}$ are observed between 2 and 15 June 2010 at $17 \mathrm{~km}$ height, indicating tropical air masses south of $25^{\circ} \mathrm{N}$ during leg 2. Two different tropopause definitions are used to identify the transition between tropical and extra-tropical air masses: the cold point

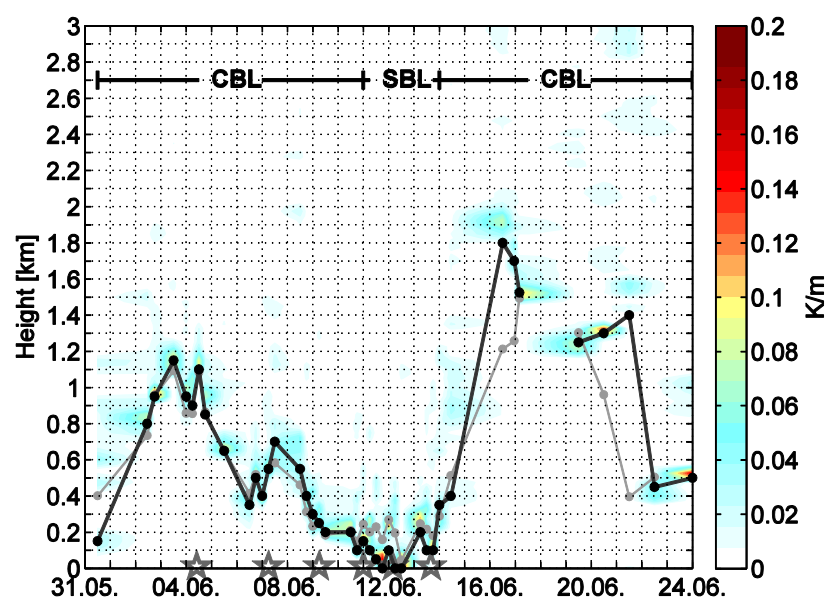

Fig. 5. Virtual potential temperature gradient (colour shading) with derived MABL heights (lines, in $\mathrm{km}$ ). The black line shows the subjectively determined MABL height from temperature and humidity profiles, and the grey line is determined theoretically (Sect. 2.2). CBL and SBL identify convective and stable boundary layers. The $24 \mathrm{~h}$ stations are marked with stars.

tropopause (CPT; Highwood and Hoskins, 1998) and the lapse rate tropopause (LRT, WMO, 1957). During leg 2, the heights of the CPT and LRT are detected between 16 and $17 \mathrm{~km}$ altitude. A change of the atmospheric regime is reflected by the decrease of the LRT height to $15 \mathrm{~km}$ in contrast to the CPT height after 15 June 2010 at the end of leg 2, as the ship enters the extratropics. The air temperature profiles also reveal typical "trade inversions" (Neiburger et al., 1961) between 1 and $2 \mathrm{~km}$ height from the beginning of the cruise until 4 June and from 16 June 2010 until the end of the cruise. Beginning on 4 June 2010, the temperature inversions descend in height, until they migrate, due to cold upwelling deep water (Fig. 3) in the Mauritanian upwelling, to intense surface inversions. The neutral and stable stratification within the lower $3 \mathrm{~km}$ of the troposphere, and therefore the upper limit of the atmospheric boundary layer during the cruise, is shown by Fig. 5. The subjectively and theoretically derived MABL heights (see Sect. 2.2) show a good agreement with each other. Differences are found above the Mauritanian upwelling, due to missing near-surface winds for the calculation of the bulk Richardson number, but also at the end of leg 2 and the beginning of leg 3 . This may be caused by our fixed $R i_{\mathrm{c}}$, which we took for convenience.

Except for the area at and south of the upwelling, observed from 11 to 14 June 2010, where we observed a SBL, the cruise was predominantly characterized by CBLs, without distinct short time or diurnal variations, considering the launch frequencies. Boundary layer heights from the surface up to $400 \mathrm{~m}$ at the upwelling area and about $400-2000 \mathrm{~m}$ above the open ocean agree with heights derived from trajectory models from previous studies along the Mauritanian coast (Carpenter et al., 2007; Quack et al., 2007). During 
Table 2. Observed mixing ratios [in ppt] of bromoform $\left(\mathrm{CHBr}_{3}\right)$, dibromomethane $\left(\mathrm{CH}_{2} \mathrm{Br}_{2}\right)$, their ratio and methyl iodide $\left(\mathrm{CH}_{3} \mathrm{I}\right)$ for the whole cruise, open ocean (leg 2 except stations 3-6, and leg 3) and coastal stations (stations 3-6). Given are the mean, the range and the standard deviation values.

\begin{tabular}{|c|c|c|c|c|c|c|c|}
\hline & \multicolumn{2}{|c|}{$\mathrm{CHBr}_{3}(\mathrm{ppt})$} & \multicolumn{2}{|c|}{$\mathrm{CH}_{2} \mathrm{Br}_{2}(\mathrm{ppt})$} & \multirow{2}{*}{$\begin{array}{l}\frac{\mathrm{CH}_{2} \mathrm{Br}_{2}}{\mathrm{CHBr}_{3}} \\
\text { Mean }\end{array}$} & \multicolumn{2}{|c|}{$\mathrm{CH}_{3} \mathrm{I}(\mathrm{ppt})$} \\
\hline & Mean (range) & stdv of mean & Mean (range) & stdv of mean & & Mean (range) & stdv of mean \\
\hline Whole cruise & $3.75(0.48-9.9)$ & 2.29 & $1.85(0.89-3.14)$ & 0.63 & 0.69 & $1.25(0.51-3.29)$ & 0.56 \\
\hline Open ocean & $1.74(0.48-9.9)$ & 1.34 & $1.28(0.89-2.70)$ & 0.31 & 0.98 & $0.93(0.51-2.11)$ & 0.24 \\
\hline Coastal stations & $5.60(4.07-8.92)$ & 1.06 & $2.37(1.87-3.14)$ & 0.31 & 0.43 & $1.55(0.90-3.29)$ & 0.62 \\
\hline
\end{tabular}

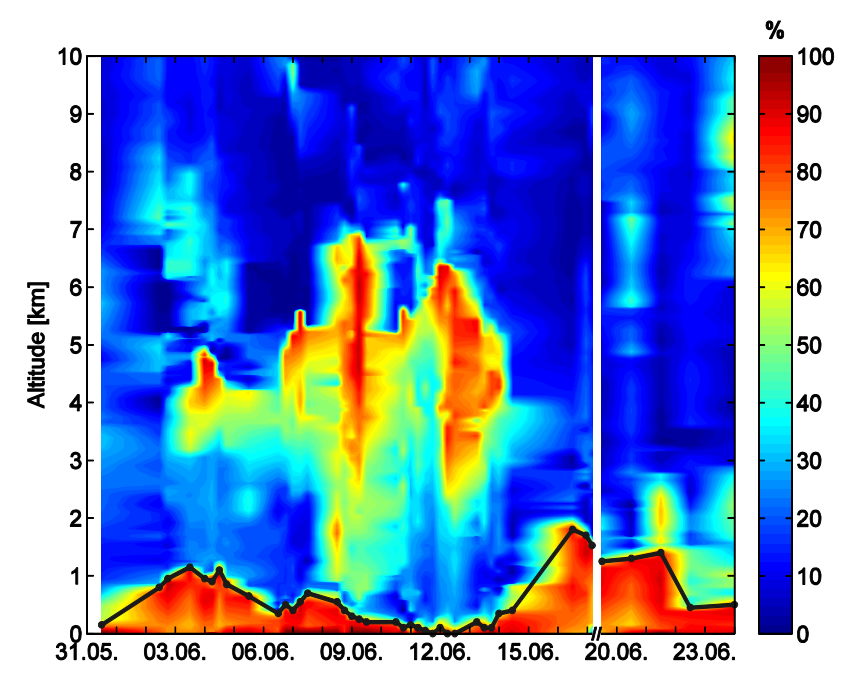

Fig. 6. Relative humidity cross sections [\%] from radiosoundings for the whole cruise. The subjectively determined MABL height $[\mathrm{km}]$ is marked by the black line. The measurement gap between leg 2 and 3 is shortened.

leg 3 the top of the boundary layer decreases from $1.4 \mathrm{~km}$ north of the Canary Islands to about $500 \mathrm{~m}$ near the coast of the Iberian Peninsula. The height of the MABL is also well reflected in the profiles of the relative humidity during the whole cruise as shown in Fig. 6. The increase of the surface/lowermost troposphere humidity between 15 and 22 June 2010 (Fig. 6) matches the observed elevation of the negative heat flux (Fig. 3). The height of the atmospheric boundary layer, determined from temperature observations, agrees very well with the surface maximum of relative humidity (Fig. 6). The vertical mixing within the MABL seems to be quite well reflected by the relative humidity observations. Especially the small extension of enhanced relative humidity above the surface of the Mauritanian upwelling from 11 to 12 June 2010 is consistent with the assumption of reduced vertical mixing (turbulence) in this area due to the positive heat flux, leading to a very stable and narrow MABL.

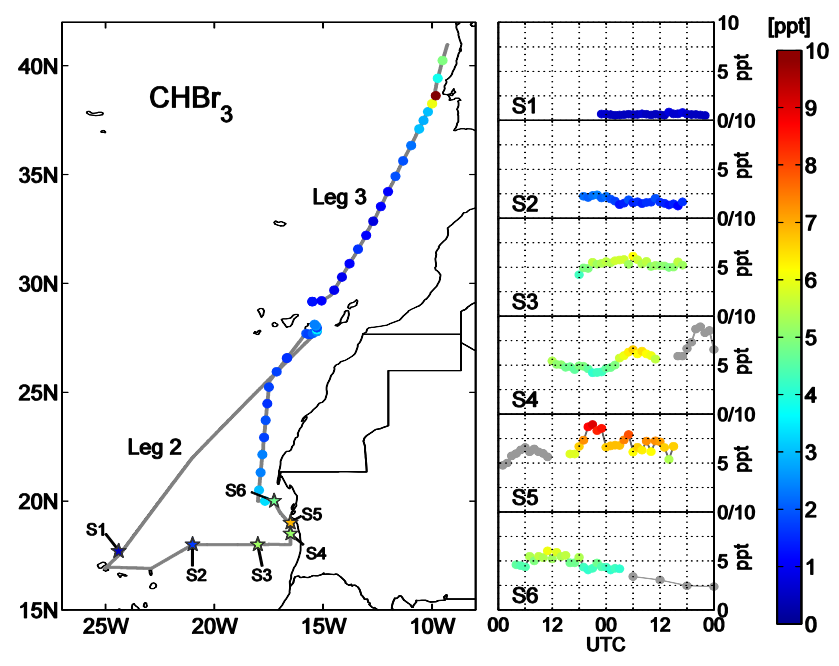

Fig. 7. Bromoform mixing ratios [ppt] measured during the DRIVE ship campaign from 31 May to 24 June 2010. Six 24 h stations (S1S6) and measurements during transit are colour-coded according to the scale on the right side.

\subsection{Atmospheric VSLS variability}

The diurnal and regional variations of halogenated trace gas abundances in the MABL have been observed with hourly measurements at six $24 \mathrm{~h}$ stations near the Cape Verde Islands and in the Mauritanian upwelling. According to the regional distribution of the diurnal stations (Fig. 1), the first two stations (S1, S2) can be combined to an open ocean cluster. The following 4 diurnal stations are furthermore declared as coastal stations (S3-S6), since they show similar physical and biological characteristics (e.g. salinity and chlorophyll $a$ ) in the surface water (Hepach et al., 2013). Six-hourly measurements were also taken from 14 June 2010 after the 6th station to the coast of Gran Canaria and during leg 3 (19-23 June 2010). Also along the coast of Gran Canaria (17 June 2010) hourly samples were taken.

An increase of atmospheric mixing ratios from the Cape Verde Islands to the Mauritanian upwelling area is found for all three trace gases: bromoform (Fig. 7), dibromomethane (Fig. 8) and methyl iodide (Fig. 9). Within the open ocean cluster, the mixing ratios ranged $0.48-9.9 \mathrm{ppt}$ 


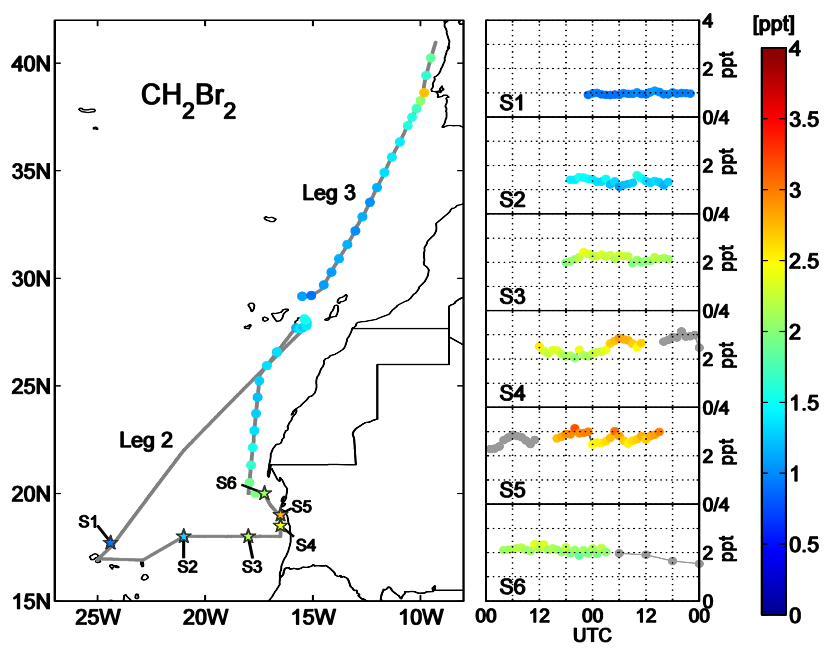

Fig. 8. Dibromomethane mixing ratios [ppt] measured during the DRIVE ship campaign from 31 May to 24 June 2010. Six $24 \mathrm{~h}$ stations (S1-S6) and measurements during transit are colour-coded according to the scale on the right side.

with a mean of $1.74 \mathrm{ppt}$ for $\mathrm{CHBr}_{3}, 0.91-1.59$ ppt with a mean of $1.28 \mathrm{ppt}$ for $\mathrm{CH}_{2} \mathrm{Br}_{2}$, and $0.63-1.32 \mathrm{ppt}$ with a mean of $0.93 \mathrm{ppt}$ for $\mathrm{CH}_{3} \mathrm{I}$. The mixing ratio of $\mathrm{CH}_{2} \mathrm{Br}_{2}$ and $\mathrm{CHBr}_{3}$ has often been observed to be around 0.1 in source areas, where the air has been influenced e.g. by fresh coastal emissions (Yokouchi, 2005 and references therein). The ratio increases towards the open ocean due to the different lifetimes of both compounds. A higher value implies an aged air mass and aged emission, while a lower value indicates fresher emissions and air masses. With an overall mean $\mathrm{CH}_{2} \mathrm{Br}_{2} / \mathrm{CHBr}_{3}$ ratio of 1.21 (Table 2) during stations 1 and 2, typical open ocean air masses were observed (Quack et al., 2004; Butler et al., 2007). At the third $24 \mathrm{~h}$ station, the bromocarbons increase to 4.22-6.12 ppt for $\mathrm{CHBr}_{3}$ and 1.962.42 ppt for $\mathrm{CH}_{2} \mathrm{Br}_{2}$, while $\mathrm{CH}_{3} \mathrm{I}$ mixing ratios remain at open ocean values. A mean $\mathrm{CH}_{2} \mathrm{Br}_{2} / \mathrm{CHBr}_{3}$ ratio of 0.41 now indicates fresher emissions. Slightly increased atmospheric mixing ratios of $\mathrm{CHBr}_{3}$ with $4.21-6.58 \mathrm{ppt}$ and of $\mathrm{CH}_{2} \mathrm{Br}_{2}$ with 2.04-2.87 ppt, and a $\mathrm{CH}_{2} \mathrm{Br}_{2} / \mathrm{CHBr}_{3}$ ratio of 0.46 are found at the 4 th $24 \mathrm{~h}$ station. For the first time, the $\mathrm{CH}_{3} \mathrm{I}$ mixing ratios show intense variations of $1.11-2.68 \mathrm{ppt}$ at this coastal station. In addition, a diurnal pattern is striking for all three VSLS at this station (S4, Fig. 7). They show a slight decrease from 12:00 UTC to 00:00 UTC followed by an increase from 06:00 UTC to 09:00 UTC on the following day, which coincides with a decrease of the MABL height and the sunrise at about 06:30 UTC. The highest atmospheric mixing ratios for all three VSLS during leg 2 were observed during the 5th station at $19^{\circ} \mathrm{N}$ and $16.5^{\circ} \mathrm{W}$. At this station also the most pronounced variations within one day are observed, with maximum mixing ratios of $8.92 \mathrm{ppt}$ for $\mathrm{CHBr}_{3}$, $3.14 \mathrm{ppt}$ for $\mathrm{CH}_{2} \mathrm{Br}_{2}$ and $3.29 \mathrm{ppt}$ for $\mathrm{CH}_{3} \mathrm{I}$. The extreme minimum of $\mathrm{CH}_{3} \mathrm{I}$ at 05:00 UTC appears as an unreliable
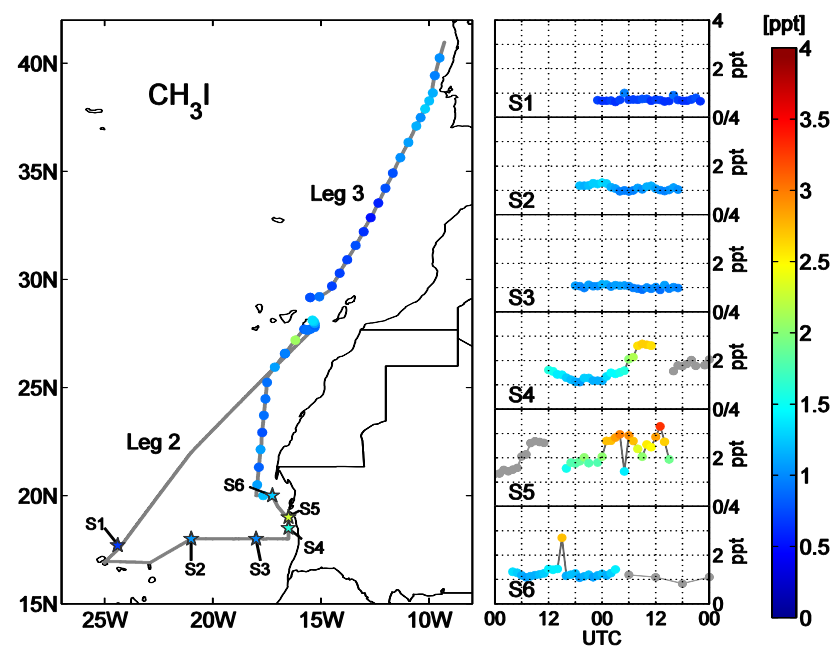

Fig. 9. Methyl iodide mixing ratios [ppt] measured during the DRIVE ship campaign from 31 May to 24 June 2010. Six $24 \mathrm{~h}$ stations (S1-S6) and measurements during transit are colour-coded according to the scale on the right side.

outlier due to the high variation of more than $1 \mathrm{ppt}$ within two hours, which is nearly consistent with the whole diurnal variation of $\mathrm{CH}_{3} \mathrm{I}$ at station 4. Although this station has the lowest $\mathrm{CH}_{2} \mathrm{Br}_{2} / \mathrm{CHBr}_{3}$ ratio of 0.40 during leg 2, this value is two to three times higher than previously reported ratios of $0.1-0.25$ for coastal source regions in the North Atlantic Ocean and the northwest of Tasmania (Carpenter et al., 2003) and tropical islands and the open Pacific Ocean (Yokouchi et al., 2005), suggesting the presence of slightly aged air masses and emissions. While the ship moved away from the Mauritanian coast, southwest of the Banc d'Arguin National Park, the last coastal station (S6) shows an increase of the $\mathrm{CH}_{2} \mathrm{Br}_{2} / \mathrm{CHBr}_{3}$ ratio to 0.44 and a decrease of the trace gas mixing ratios to $4.85 \mathrm{ppt}$ (range: $4.07-6.01 \mathrm{ppt}$ ) for bromoform, $2.11 \mathrm{ppt}$ (1.87-2.34 ppt) for dibromomethane and $1.28 \mathrm{ppt}(1.07-2.71 \mathrm{ppt})$ for methyl iodide. The extreme $\mathrm{CH}_{3}$ I maximum at 15:00 UTC appears again as an outlier. A further decrease of the atmospheric abundances is observed up to $22^{\circ} \mathrm{N}$. Mixing ratios thereafter remain nearly constant to the Canary Islands, except for methyl iodide, which shows a maximum of 2 ppt southwest of Gran Canaria. Minor variations occur for all three VSLS at the Canarian coast, while the means of $2.29 \mathrm{ppt} \mathrm{CHBr}_{3}, 1.38 \mathrm{ppt} \mathrm{CH}_{2} \mathrm{Br}_{2}$ and $1.14 \mathrm{ppt}$ $\mathrm{CH}_{3} \mathrm{I}$ are in agreement with open ocean values and remain at this level until $35^{\circ} \mathrm{N}$. An increase of the brominated halocarbons is observed as the cruise approaches the Portuguese coast. While dibromomethane only reaches $2.70 \mathrm{ppt}$, bromoform reaches the highest mixing ratio of $9.9 \mathrm{ppt}$ during the whole DRIVE cruise close to Lisbon (Portugal), leading to a ratio of both compounds of 0.27 . Raimund et al. (2011) related the increased abundances of halogenated trace gases in the Iberian upwelling system to strong intertidal coastal 
Table 3. Correlation coefficients of bromoform $\left(\mathrm{CHBr}_{3}\right)$, dibromomethane $\left(\mathrm{CH}_{2} \mathrm{Br}_{2}\right)$ and methyl iodide $\left(\mathrm{CH}_{3} \mathrm{I}\right)$ mixing ratios with wind speed $\left(w_{\text {spd }}\right)$, wind direction $\left(w_{\text {dir }}\right)$, surface air pressure $(p)$, surface air temperature $\left(T_{\mathrm{SAT}}\right)$, sea surface temperature $\left(T_{\mathrm{SST}}\right)$, temperature difference $\left(\Delta T=T_{\mathrm{SAT}}-T_{\mathrm{SST}}\right)$, relative humidity $(U)$, and MABL height. Whole cruise (leg 2 and 3$)$ includes $n=181 \mathrm{samples}$ for all parameters except MABL height (30 samples), open ocean (leg 2, except stations 3-6 and leg 3) includes $n=85$ samples for all parameters except MABL height (15 samples) and coastal stations (stations 3-6) include $n=96$ samples for all parameters except MABL height (15 samples). Bold coefficients have a $p$ value of less than $5 \%$.

\begin{tabular}{|c|c|c|c|c|c|c|c|c|c|}
\hline & \multicolumn{3}{|c|}{$\mathrm{CHBr}_{3}$} & \multicolumn{3}{|c|}{$\mathrm{CH}_{2} \mathrm{Br}_{2}$} & \multicolumn{3}{|c|}{$\mathrm{CH}_{3} \mathrm{I}$} \\
\hline & Whole cruise & Open ocean & Coastal stations & Whole cruise & Open ocean & Coastal stations & Whole cruise & Open ocean & Coastal stations \\
\hline$w_{\text {spd }}$ & 0.23 & 0.23 & -0.17 & 0.27 & 0.32 & -0.05 & 0.24 & 0.37 & 0.06 \\
\hline$w_{\text {dir }}$ & -0.49 & -0.31 & 0.04 & -0.52 & -0.32 & -0.18 & -0.28 & -0.12 & -0.01 \\
\hline$p$ & -0.76 & -0.01 & $-\mathbf{0 . 5 3}$ & -0.82 & -0.11 & -0.71 & -0.64 & $-\mathbf{0 . 3 3}$ & -0.52 \\
\hline$T_{\mathrm{SAT}}$ & -0.04 & -0.68 & 0.42 & 0.05 & -0.67 & 0.59 & 0.24 & -0.26 & 0.48 \\
\hline$T_{\mathrm{SST}}$ & -0.45 & -0.70 & -0.04 & -0.39 & -0.69 & 0.13 & -0.21 & -0.24 & 0.00 \\
\hline$\Delta \mathrm{T}$ & 0.70 & 0.17 & 0.64 & 0.71 & 0.18 & 0.63 & 0.73 & -0.13 & 0.68 \\
\hline $\mathrm{U}$ & 0.52 & 0.47 & -0.16 & 0.50 & 0.58 & -0.32 & 0.21 & 0.50 & -0.38 \\
\hline MABL & -0.81 & -0.32 & -0.60 & -0.82 & -0.40 & -0.62 & -0.64 & -0.58 & -0.70 \\
\hline
\end{tabular}
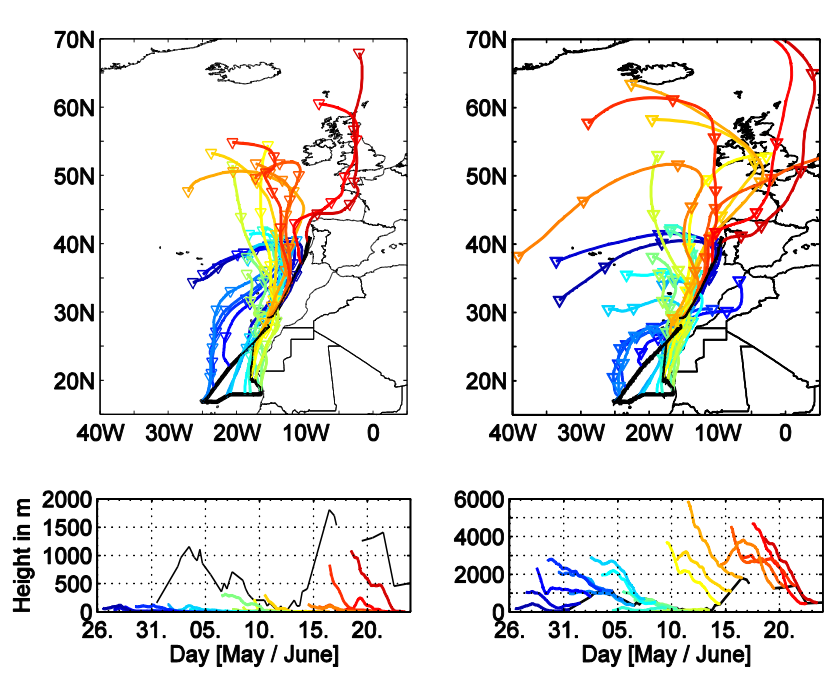

Fig. 10. HYSPLIT 5-day backward trajectories: initiated at the surface (left side) and at the top of the determined marine atmospheric boundary layer (right side) each day at 12:00 UTC. The colours of the trajectories indicate the time when the specific trajectory reached the ships position, e.g. blue at the beginning and red at the end of the cruise. The upper plots show the horizontal and the lower plots the vertical distribution of the trajectories. The black line indicates the height of the MABL. Trajectory and MABL heights are given in $[\mathrm{m}]$.

sources and advection of halocarbon-enriched coastal upwelling, but also anthropogenic sources as river outflow are likely (Quack and Wallace, 2003).

\subsubsection{Air mass origin}

Investigating the air mass history is a good way to reveal potential source regions (Fig. 10). Surface (STs) and boundary layer height trajectories (BLTs) indicate primarily northerly origin of air masses during the cruise. From 31 May to 3 June 2010 the air masses mainly arrive from the Azores.
While the HYSPLIT model projects that the STs do not extend $100 \mathrm{~m}$ altitude, the BLTs arise from about $3 \mathrm{~km}$ height with little Moroccan influence. A high-pressure system, located between the Azores and the coast of Portugal, deflects the air masses up to $40^{\circ} \mathrm{N}-50^{\circ} \mathrm{N}$, close to the coast of Portugal, and redirects, in combination with the trade winds, the air southwards to the ship. From 6 to 17 June 2010 the light blue, yellow and orange trajectories show a more varying origin, between $30^{\circ} \mathrm{N}$ and $60^{\circ} \mathrm{N}$. Most of the STs descend from heights up to $300 \mathrm{~m}$ to the surface 1-2 days before hitting the ship. This air mass descent is typical for a high-pressure system. Reaching the ground, the surface inversions, as described in Sect. 3.1.1, prevent the air masses from ascending. The resulting stable, isolated and very low boundary layer leads to similar origins of offshore STs and BLTs. In the area of the Mauritanian upwelling, from 10 to 15 June 2010, the trajectories also pass the west coast of Mauritania and the western part of West Sahara within the last $24 \mathrm{~h}$; however, the air approaches predominantly from the North Atlantic Ocean between $45^{\circ} \mathrm{N}$ and $60^{\circ} \mathrm{N}$ and west of Great Britain. These origins have also been observed in previous measurement campaigns (Quack et al., 2007; Carpenter et al., 2010). In comparison, the BLTs are spatially more widespread over the North Atlantic Ocean, indicating the higher wind speed in the free troposphere. At leg 3 the STs and BLTs have a midto polar latitude origin $\left(30^{\circ} \mathrm{N}\right.$ to $\left.80^{\circ} \mathrm{N}\right)$; however, continental influences from northern Europe dominate for the BLTs east of the prime meridian.

\subsection{Meteorological constraints on VSLS variability}

To distinguish meteorological constraints on the VSLS abundances we correlate meteorological parameters with bromoform, dibromomethane and methyl iodide (Table 3). In the following we highlight the significant correlations. We find a weak but significant correlation between the trace gas abundances and the wind speed for the open ocean and for the whole cruise. In contrast, the wind direction reveals 
an overall anti-correlation of -0.5 for the brominated halocarbons and -0.3 for methyl iodide. This means increased VSLS abundances generally coincide with a westerly wind component and reduced abundances coincide with an easterly wind component during the whole cruise. To evaluate land-sea breeze constraints on the trace gas abundances, we take a look to stations 4 and 5 . Indeed, both stations show typical land-sea breeze caused diurnal variations in wind speed and direction. The atmospheric abundances reveal significant high correlations of $r=0.82$ for bromoform, $r=0.73$ for dibromomethane and 0.82 for methyl iodide with the wind direction at station 4 in contrast to the overall anti-correlation (not shown here). At the 4th station, trace gas abundances increase with an increasing easterly component of the wind, while the abundances decrease with an increasing westerly wind component, related to differences in air mass origin (coastal versus open ocean), as also shown by the trajectories in Fig. 10. At the 5th station, 3-hourly trajectory calculations reveal ground-level air masses with potential coastal and anthropogenic influence along the coast of Western Sahara, with air masses from the open ocean leading to an increase of the dibromomethane abundances $(r=-0.55)$ in contrast to the variations of bromoform and methyl iodide, which seem more related to local sources (not shown here). Anti-correlations of -0.6 to -0.8 are also found between the air pressure and the trace gases, caused by predominantly higher pressures at higher latitudes, and over open ocean, with lower VSLS abundances and vice versa for the coastal stations 3-6. At these stations, the anti-correlation is further dominated by the atmospheric tides of the air pressure and amounts to -0.5 for bromoform and methyl iodide and even -0.7 for dibromomethane. Whether or not this relation between the 12-hourly oscillations of sea level pressure and the trace gas variations can be generalized should be investigated in more detail in a future study. The relative humidity correlates with the trace gases in the open ocean with $r=0.5$ to 0.6 and at the coastal stations with $r=-0.2$ to -0.4 (Table 3). The vertical distribution of the relative humidity has been a good indicator for mixing in and thickness of the MABL (Sect. 3.1.1), which may point to an additional correlation between the surface relative humidity and the VSLS abundances reflected by the high correlation for the whole cruise. However, over the upwelling areas this relationship does not hold. The cold upwelling water creates a positive $\Delta T$ and a negative sensible heat flux that suppresses convection and leads to a low relative humidity, which is in contrast to the VSLS abundances. This would explain the reversed correlation above the upwelling. The VSLS abundances are significantly anti-correlated with SAT and SST variations in the open ocean and correlated with SAT in the coastal upwelling. The sensible heat flux, reflected by the temperature difference $\Delta T\left(T_{\mathrm{SAT}}-T_{\mathrm{SST}}\right)$, correlates with $r$ values of at least 0.7 for all trace gases during the whole cruise and at least 0.6 at the coastal stations. The combination of higher air and lower water tempera-

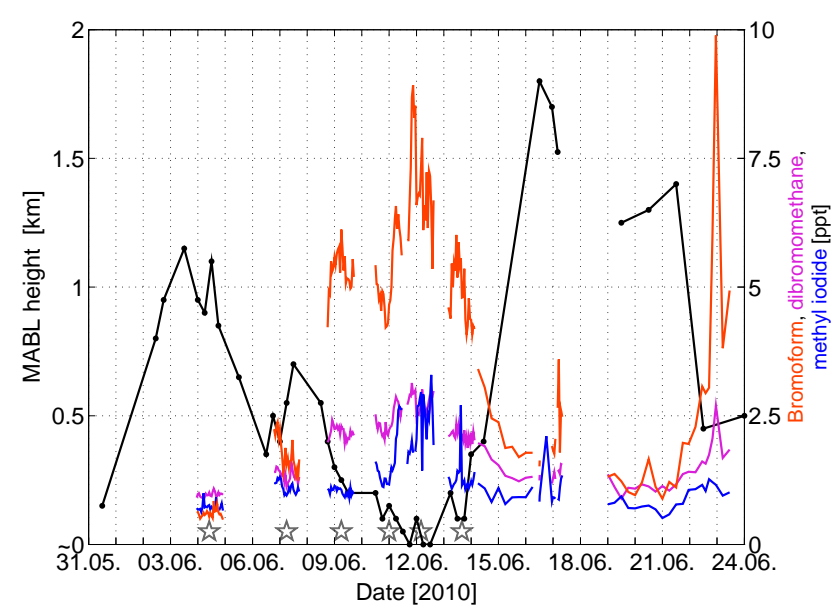

Fig. 11. Comparison of MABL height (left scale, in km) with bromoform, dibromomethane and methyl iodide mixing ratios (right scale, in ppt).

tures coincides with increased trace gas abundances and vice versa, although this is inappropriate for evaporation. This shows that from surface relative humidity one cannot simply infer VSLS abundances or even the MABL height. The temperature difference $\Delta T$ further affects the atmospheric stability near the surface. The cold upwelling water at the Mauritanian upwelling converges with warm air from the African coast (Sect. 3.2.1) and creates a negative sensible heat flux between air and water, which cools the near-surface air layer. As a result, surface inversions, or at least a stable stratification of the lower atmosphere, are formed, which suppresses the vertical movement of air. The resulting reduced volume of air that is available for mixing leads to a low MABL height. An anti-correlation of -0.74 between $\Delta T$ and the MABL height at the coastal stations confirms this (not shown here). A comparison of bromoform, dibromomethane and methyl iodide with the MABL height during the whole cruise is shown in Fig. 11. Higher VSLS concentrations obviously coincide with a lower MABL height and vice versa. During leg 2 the highest mixing ratios are observed while the MABL height stays between the surface and $500 \mathrm{~m}$ in the area of the Mauritanian upwelling (stations 3-6). On the other hand, low mixing ratios measured over the open ocean coincide with a high boundary layer top. The transit towards Vigo (Spain) also shows a decrease of the MABL height and an increase of the three VSLS mixing ratios close to the Iberian coast. In contrast to the other meteorological parameters we derive anti-correlations between the atmospheric trace gas abundances and the MABL height for all regions, reflecting the distinct connection between these variables. The linear correlations of bromoform, dibromomethane and methyl iodide with the MABL height for the whole cruise are represented in Fig. 12a-c. Bromoform, with $r=-0.81$, and dibromomethane, with $r=-0.82$, show the 

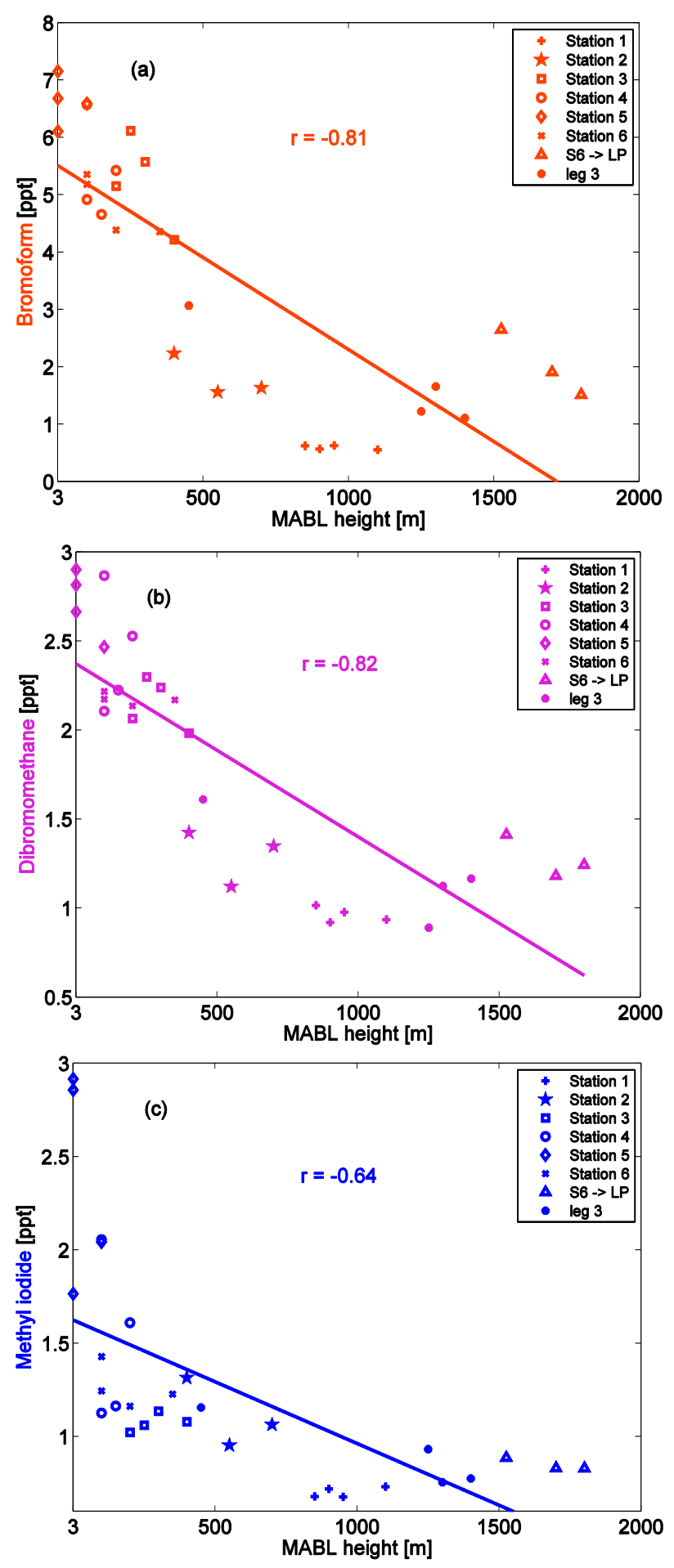

Fig. 12. Correlation between MABL height [m] and (a) bromoform, (b) dibromomethane and (c) methyl iodide abundances [ppt] for the whole cruise. The different markers reflect the different locations: leg 2 including stations 1-6, the transit between station 6 and Las Palmas, and leg 3. The according $p$ values are less than $1 \%$ for all three correlations, with each including 30 samples. highest anti-correlations. Although the anti-correlation of methyl iodide, $r=-0.64$, is not as high as for the brominated halocarbons, it is significant at the $99 \%$ level.

\subsection{Correlations of meteorological parameters and atmospheric abundances with VSLS fluxes}

The sea-to-air fluxes, which are calculated depending on wind speed and the concentration gradient $\Delta c$ between sea water and air (Sect. 2.1), show significant correlations with wind speed and anti-correlations with MABL height (Table 4). The inverse relationship of atmospheric VSLS to MABL height as described in Sect. 3.3 should lead to lower sea-to-air fluxes, $F$, as lower MABL heights lead to higher atmospheric mixing ratios, decreasing the concentration gradient, $\Delta c$ (Eq. 2). However, higher sea-to-air fluxes are observed in the lower MABL height areas for dibromomethane and bromoform, with an accordingly positive relationship of $F$ to $\Delta T$ (Table 4). This is due to elevated sea water production of brominated VSLS in the cold waters, leading to a large increase in the concentration gradient, which masks the flux suppression by the higher atmospheric mixing ratios (Hepach et al., 2013). Also the elevated atmospheric mixing ratios of methyl iodide have no effect on the fluxes, because methyl iodide is strongly supersaturated in the sea surface water throughout the entire cruise. On the other hand, the observed sea-to-air fluxes reveal correlations with the atmospheric VSLS abundances (Table 5), showing that MABL height and sea-to-air fluxes in combination add to the VSLS variations in the atmosphere. The detailed analysis of the seato-air fluxes, their driving factors, such as the sea water concentrations, and their influences on the atmospheric VSLS abundances are discussed in detail in Hepach et al. (2013).

\section{Summary}

The diurnal and regional variability of atmospheric VSLS has been investigated during the DRIVE ship campaign in May/June 2010 in the eastern tropical and subtropical North Atlantic Ocean. Additionally, we analyse meteorological influences on the observed VSLS mixing ratios using simultaneous high-resolution data. VSLS measurements were conducted hourly at six $24 \mathrm{~h}$ stations and during passage from the coast of Mauritania to Vigo (Spain), resulting in a total of 187 atmospheric VSLS measurements during DRIVE. We concentrated our investigation on three trace gases: bromoform, dibromomethane and methyl iodide. Higher mean VSLS mixing ratios were found over the Mauritanian upwelling region $(5.60 \mathrm{ppt}, 2.37 \mathrm{ppt}$ and $1.50 \mathrm{ppt}$ for bromoform, dibromomethane and methyl iodide, respectively) than over the open ocean (1.74 ppt, $1.28 \mathrm{ppt}$ and $0.93 \mathrm{ppt}$ for bromoform, dibromomethane and methyl iodide, respectively). The upwelling region also shows diurnal variations of the VSLS with highest fluctuations between maximum and minimum 
Table 4. Correlation coefficients of bromoform $\left(\mathrm{CHBr}_{3}\right)$, dibromomethane $\left(\mathrm{CH}_{2} \mathrm{Br}_{2}\right)$ and methyl iodide $\left(\mathrm{CH}_{3} \mathrm{I}\right)$ fluxes with wind speed $\left(w_{\text {spd }}\right)$, wind direction $\left(w_{\text {dir }}\right)$, surface air pressure $(p)$, surface air temperature $\left(T_{\mathrm{SAT}}\right)$, sea surface temperature $\left(T_{\mathrm{SST}}\right)$, temperature difference $\left(\Delta T=T_{\mathrm{SAT}}-T_{\mathrm{SST}}\right)$, relative humidity $(U)$, and MABL height. Whole cruise (leg 2 and 3 ) includes $n=109$ samples for all parameters except MABL height (21 samples), open ocean (leg 2 except stations 3-6 and leg 3) includes $n=37$ samples for all parameters except MABL height (8 samples) and coastal stations (stations 3-6) include $n=70$ samples for all parameters except MABL height (13 samples). Bold coefficients have a $p$ value of less than $5 \%$.

\begin{tabular}{|c|c|c|c|c|c|c|c|c|c|}
\hline & \multicolumn{3}{|c|}{$\mathrm{CHBr}_{3}$ flux } & \multicolumn{3}{|c|}{$\mathrm{CH}_{2} \mathrm{Br}_{2}$ flux } & \multicolumn{3}{|c|}{$\mathrm{CH}_{3} \mathrm{I}$ flux } \\
\hline & Whole cruise & Open ocean & Coastal stations & Whole cruise & Open ocean & Coastal stations & Whole cruise & Open ocean & Coastal stations \\
\hline$w_{\text {spd }}$ & 0.37 & 0.19 & 0.48 & 0.54 & 0.84 & 0.71 & 0.54 & 0.52 & 0.61 \\
\hline$w_{\text {dir }}$ & -0.37 & 0 & 0.06 & -0.51 & 0.09 & -0.13 & 0.07 & -0.04 & 0.07 \\
\hline$p$ & -0.67 & -0.10 & -0.57 & -0.81 & -0.71 & -0.73 & -0.08 & -0.30 & -0.14 \\
\hline$T_{\mathrm{SAT}}$ & -0.08 & -0.13 & 0.15 & -0.06 & -0.75 & 0.27 & -0.20 & -0.4 & -0.21 \\
\hline$T_{\mathrm{SST}}$ & -0.54 & -0.29 & -0.31 & -0.51 & -0.84 & -0.17 & -0.24 & -0.55 & -0.36 \\
\hline$\Delta \mathrm{T}$ & 0.76 & 0.35 & 0.67 & 0.75 & -0.15 & 0.63 & 0.12 & 0.18 & 0.22 \\
\hline $\mathrm{U}$ & -0.04 & -0.14 & -0.43 & -0.02 & 0.65 & -0.61 & -0.08 & 0.21 & -0.27 \\
\hline MABL & -0.58 & 0.26 & -0.58 & -0.68 & -0.93 & -0.68 & -0.27 & -0.12 & -0.59 \\
\hline
\end{tabular}

Table 5. Correlation coefficients of bromoform $\left(\mathrm{CHBr}_{3}\right)$, dibromomethane $\left(\mathrm{CH}_{2} \mathrm{Br}_{2}\right)$ and methyl iodide $\left(\mathrm{CH}_{3} \mathrm{I}\right)$ fluxes with according mixing ratios. Whole cruise (leg 2 and 3) includes $n=109$ samples, open ocean (leg 2 except stations 3-6 and leg 3) includes $n=37$ samples and coastal stations (stations 3-6) include $n=70$ samples. Bold coefficients have a $p$ value of less than $5 \%$.

\begin{tabular}{|c|c|c|c|c|c|c|c|c|c|}
\hline & \multicolumn{3}{|c|}{$\mathrm{CHBr}_{3}$ flux } & \multicolumn{3}{|c|}{$\mathrm{CH}_{2} \mathrm{Br}_{2}$ flux } & \multicolumn{3}{|c|}{$\mathrm{CH}_{3} \mathrm{I}$ flux } \\
\hline & Whole cruise & Open ocean & Coastal stations & Whole cruise & Open ocean & Coastal stations & Whole cruise & Open ocean & Coastal stations \\
\hline $\mathrm{CHBr}_{3}$ mixing ratio & 0.58 & -0.20 & $\mathbf{0 . 3 3}$ & 0.68 & 0.60 & 0.39 & -0.08 & 0.22 & -0.16 \\
\hline $\mathrm{CH}_{2} \mathrm{Br}_{2}$ mixing ratio & 0.61 & -0.05 & 0.40 & 0.71 & 0.56 & 0.49 & -0.04 & 0.33 & -0.08 \\
\hline $\mathrm{CH}_{3} \mathrm{I}$ mixing ratio & 0.62 & -0.09 & 0.50 & 0.66 & 0.62 & 0.51 & 0.09 & 0.21 & 0.12 \\
\hline
\end{tabular}

of $3.57 \mathrm{ppt}$ for bromoform, $0.83 \mathrm{ppt}$ for dibromomethane and $1.85 \mathrm{ppt}$ for methyl iodide. A strong coastal gradient of the VSLS is also observed towards Lisbon (Portugal), where we detect the highest bromoform mixing ratio of the whole cruise of 9.8 ppt.

The air mass origin is investigated by 5-day backward trajectories starting at the surface and at the top of the determined marine atmospheric boundary layer. We identify a predominantly North Atlantic origin of the air due to the prevailing NW winds during the whole cruise, with minor coastal influence at the Mauritanian upwelling area.

To distinguish atmospheric constraints on the VSLS we compare several meteorological parameters with the trace gas abundances. Although we do not find an overall relationship with the wind, we detect a significant correlation between VSLS abundance and easterly wind direction changes $(r>0.7)$ at the 4 th station, northwest of Nouakchott (Mauritania), which is linked to land-sea breeze influence. We find a strong anti-correlation between air-sea surface temperature difference and MABL height, derived from radiosoundings. The MABL heights are dependent on the location, as we determine heights from surface level to only $400 \mathrm{~m}$ in the upwelling region and between 400 and $1700 \mathrm{~m}$ over the open ocean. In the Mauritanian upwelling a stable boundary layer leads to stable atmospheric conditions near the surface, due to warm air flowing over cold upwelling water, suppressing the mixing of air. In the open ocean part of the cruise, the top of the MABL is limited by trade in- versions. Overall a significant anti-correlation between the VSLS mixing ratios and the marine atmospheric boundary layer height is found. With correlation coefficients of $r=$ -0.81 for bromoform, $r=-0.82$ for dibromomethane and $r=-0.64$ for methyl iodide, the MABL height appears to have a significant influence on the trace gas mixing ratios. This relationship may help explain observed events in the tropical eastern Atlantic with increased atmospheric VSLS mixing ratios in the Mauritanian upwelling. Whether this influence can also be found in different seasons or other oceanic regions should be addressed in future studies. Of particular interest would be to investigate other oceanic upwelling regions, which are expected to also have high VSLS sources as the Mauritanian upwelling/Cape Verde Islands region does.

Acknowledgements. We thank the authorities of Cape Verde, Mauritania, Portugal and Spain for the permissions to work in their territorial waters. We acknowledge the NOAA Air Resources Laboratory (ARL) for the provision of NCEP reanalysis data and the HYSPLIT transport and dispersion model used in this publication. We thank S. Tegtmeier for helpful comments and M. Toohey for proofreading. We acknowledge the support of the captain and crew of R/V Poseidon as well as Hermann Bange, chief scientist of P399 legs 2 and 3. We also thank the 3 anonymous reviewers and the editor Bill Sturges for the helpful comments. Financial support for this study was provided by the BMBF grant SOPRAN II FKZ 03F0611A. This work also contributes to European Union's 
Seventh Framework Programme FP7/2007-2013 under grant agreement no. 226224 - SHIVA.

The service charges for this open access publication have been covered by a Research Centre of the Helmholtz Association.

Edited by: W. T. Sturges

\section{References}

Atlas, E., Pollock, W., Greenberg, J., Heidt, L., and Thompson, A.: Alkyl nitrates, nonmethane hydrocarbons, and halocarbon gases over the equatorial Pacific Ocean during SAGA-3, J. Geophys. Res.-Atmos., 98, 16933-16947, doi:10.1029/93JD01005, 1993.

Bange, H., Atlas, E., Bahlmann, E., Baker, A., Bracher, A., Cianca, A., Dengler, M., Fuhlbrügge, S., Großmann, K., Hepach, H., Lavrič, J., Löscher, C., Krüger, K., Orlikowska, A., Peeken, I., Quack, B., Schafstall, J., Steinhoff, T., Williams, J., and Wittke, F.: FS Poseidon cruise report P399 legs 2 and 3, 74, IFMGEOMAR, Kiel, Germany, 2011.

Butler, J., King, D., Lobert, J., Montzka, S., Yvon-Lewis, S., Hall, B., Warwick, N., Mondeel, D., Aydin, M., and Elkins, J.: Oceanic distributions and emissions of short-lived halocarbons, Global Biogeochem. Cy., 21, doi:10.1029/2006GB002732, 2007.

Carpenter, L. and Liss, P.: On temperate sources of bromoform and other reactive organic bromine gases, J. Geophys. Res.-Atmos., 105, 20539-20547, doi:10.1029/2000JD900242, 2000.

Carpenter, L., Liss, P., and Penkett, S.: Marine organohalogens in the atmosphere over the Atlantic and Southern Oceans, J. Geophys. Res.-Atmos., 108, 4256, doi:10.1029/2002JD002769, 2003.

Carpenter, L., Wevill, D., Hopkins, J., Dunk, R., Jones, C., Hornsby, K., and McQuaid, J.: Bromoform in tropical Atlantic air from 25 degrees N to 25 degrees S, Geophys. Res. Lett., 34, L11810, doi:10.1029/2007GL029893, 2007.

Carpenter, L., Fleming, Z., Read, K., Lee, J., Moller, S., Hopkins, J., Purvis, R., Lewis, A., Muller, K., Heinold, B., Herrmann, H., Fomba, K., van Pinxteren, D., Muller, C., Tegen, I., Wiedensohler, A., Muller, T., Niedermeier, N., Achterberg, E., Patey, M., Kozlova, E., Heimann, M., Heard, D., Plane, J., Mahajan, A., Oetjen, H., Ingham, T., Stone, D., Whalley, L., Evans, M., Pilling, M., Leigh, R., Monks, P., Karunaharan, A., Vaughan, S., Arnold, S., Tschritter, J., Pohler, D., Friess, U., Holla, R., Mendes, L., Lopez, H., Faria, B., Manning, A., and Wallace, D.: Seasonal characteristics of tropical marine boundary layer air measured at the Cape Verde Atmospheric Observatory, J. Atmos. Chem., 67, 87-140, doi:10.1007/s10874-011-9206-1, 2010.

Dessens, O., Zeng, G., Warwick, N., and Pyle, J.: Short-lived bromine compounds in the lower stratosphere; impact of climate change on ozone, Atmospheric Science Letters, 10, 201-206, doi:10.1002/asl.236, 2009.

Garratt, J.: The internal boundary-layer - a review, Bound.-Lay. Meteorol., 50, 171-203, doi:10.1007/BF00120524, 1990.

Gschwend, P., Macfarlane, J., and Newman, K.: Volatile halogenated organic-compounds released to seawater from temperate marine macroalgae, Science, 227, 1033-1035, doi:10.1126/science.227.4690.1033, 1985.
Hepach, H., Quack B., Ziska F., Fuhlbrügge, S., Atlas, E. L., Peeken, I., Krüger, K., and Wallace, D. W. R.: Drivers of diel and regional variations of halocarbon emissions from the tropical North East Atlantic, in preparation, 2013.

Highwood, E. and Hoskins, B.: The tropical tropopause, Q. J. Roy. Meteorol. Soc., 124, 1579-1604, doi:10.1256/smsqj.54910, 1998.

Hossaini, R., Chipperfield, M., Dhomse, S., Ordonez, C., SaizLopez, A., Abraham, N., Archibald, A., Braesicke, P., Telford, P., Warwick, N., Yang, X., and Pyle, J.: Modelling future changes to the stratospheric source gas injection of biogenic bromocarbons, Geophys. Res. Lett., 39, L20813, doi:10.1029/2012GL053401, 2012.

Kalnay, E., Kanamitsu, M., Kistler, R., Collins, W., Deaven, D., Gandin, L., Iredell, M., Saha, S., White, G., Woollen, J., Zhu, Y., Chelliah, M., Ebisuzaki, W., Higgins, W., Janowiak, J., Mo, K., Ropelewski, C., Wang, J., Leetmaa, A., Reynolds, R., Jenne, R., and Joseph, D.: The NCEP/NCAR 40-year reanalysis project, B. Am. Meteorol. Soc., 77, 437-471, doi:10.1175/15200477(1996)077<0437:TNYRP>2.0.CO;2, 1996.

Kistler, R., Kalnay, E., Collins, W., Saha, S., White, G., Woollen, J., Chelliah, M., Ebisuzaki, W., Kanamitsu, M., Kousky, V., van den Dool, H., Jenne, R., and Fiorino, M.: The NCEP-NCAR 50-year reanalysis: Monthly means CD-ROM and documentation, B. Am. Meteorol. Soc., 82, 247-267, doi:10.1175/15200477(2001)082<0247:TNNYRM>2.3.CO;2, 2001.

Kloster, S., Six, K., Feichter, J., Maier-Reimer, E., Roeckner, E., Wetzel, P., Stier, P., and Esch, M.: Response of dimethylsulfide (DMS) in the ocean and atmosphere to global warming, J. Geophys. Res.-Biogeosci., 112, G03005, doi:10.1029/2006JG000224, 2007.

Ko, M. K. W., Poulet, G., and Blake, D. R.: Very short-lived halogen and sulfur substances, Scientific assessment of ozone depletion: 2002, Global Ozone Research and Monitoring Project. Report No. 47, Chapter 2, World Meteorological Organization, Geneva, 2003.

Krüger, K. and Quack, B.: Introduction to special issue: the TransBrom Sonne expedition in the tropical West Pacific, Atmos. Chem. Phys. Discuss., 12, 1401-1418, doi:10.5194/acpd-121401-2012, 2012.

Manley, S. and Dastoor, M.: Methyl-iodide (CH3I) production by kelp and assoviated microbes, Marine Biol., 98, 477-482, doi:10.1007/BF00391538, 1988.

Montzka, S. A. and Reimann, S.: Ozone-depleting substances and related chemicals, Scientific Assessment of Ozone Depletion: 2010, Global Ozone Research and Monitoring Project - Report No. 52, Geneva, Switzerland, 2011.

Moore, R. and Tokarczyk, R.: Volatile biogenic halocarbons in the northwest Atlantic, Global Biogeochem. Cy., 7, 195-210, doi:10.1029/92GB02653, 1993.

Neiburger, M., Johnson, D., and Chien, C.: Studies of the structure of the atmosphere over the Eastern Pacific Ocean in summer: I. The inversion over the Eastern North Pacific Ocean, 1, Univ. of Calif., Publications in Meteorology, 94 pp., 1961.

Nightingale, P., Malin, G., Law, C., Watson, A., Liss, P., Liddicoat, M., Boutin, J., and Upstill-Goddard, R.: In situ evaluation of air-sea gas exchange parameterizations using novel conservative and volatile tracers, Global Biogeochem. Cy., 14, 373-387, doi:10.1029/1999GB900091, 2000. 
O’Brien, L., Harris, N., Robinson, A., Gostlow, B., Warwick, N., Yang, X., and Pyle, J.: Bromocarbons in the tropical marine boundary layer at the Cape Verde Observatory - measurements and modelling, Atmos. Chem. Phys., 9, 9083-9099, doi:10.5194/acp-9-9083-2009, 2009.

Pyle, J., Warwick, N., Yang, X., Young, P., and Zeng, G.: Climate/chemistry feedbacks and biogenic emissions, Phil. Trans. Roy. Soc. a-Mathematical Phys. Eng. Sci., 365, 1727-1740, doi:10.1098/rsta.2007.2041, 2007.

Quack, B. and Wallace, D.: Air-sea flux of bromoform: Controls, rates, and implications, Global Biogeochem. Cy., 17, 1023, doi:10.1029/2002GB001890, 2003.

Quack, B., Atlas, E., Petrick, G., Stroud, V., Schauffler, S., and Wallace, D.: Oceanic bromoform sources for the tropical atmosphere, Geophys. Res. Lett., 31, L23S05, doi:10.1029/2004GL020597, 2004.

Quack, B., Atlas, E., Petrick, G., and Wallace, D.: Bromoform and dibromomethane above the Mauritanian upwelling: Atmospheric distributions and oceanic emissions, J. Geophys. Res.-Atmos., 112, D09312, doi:10.1029/2006JD007614, 2007.

Raimund, S., Quack, B., Bozec, Y., Vernet, M., Rossi, V., Garcon, V., Morel, Y., and Morin, P.: Sources of short-lived bromocarbons in the Iberian upwelling system, Biogeosciences, 8, 15511564, doi:10.5194/bg-8-1551-2011, 2011.

Read, K., Mahajan, A., Carpenter, L., Evans, M., Faria, B., Heard, D., Hopkins, J., Lee, J., Moller, S., Lewis, A., Mendes, L., McQuaid, J., Oetjen, H., Saiz-Lopez, A., Pilling, M., and Plane, J.: Extensive halogen-mediated ozone destruction over the tropical Atlantic Ocean, Nature, 453, 1232-1235, doi:10.1038/nature07035, 2008.

Relvas, P., and Barton, E.: Mesoscale patterns in the Cape Sao Vicente (Iberian Peninsula) upwelling region, J. Geophys. Res.Ocean., 107, 3164, doi:10.1029/2000JC000456, 2002.

Schmittner, A., Oschlies, A., Matthews, H., and Galbraith, E.: Future changes in climate, ocean circulation, ecosystems, and biogeochemical cycling simulated for a business-as-usual $\mathrm{CO}_{(2)}$ emission scenario until year $4000 \mathrm{AD}$, Global Biogeochem. Cy., 22, GB1013, doi:10.1029/2007GB002953, 2008.

Seibert, P., Beyrich, F., Gryning, S., Joffre, S., Rasmussen, A., and Tercier, P.: Review and intercomparison of operational methods for the determination of the mixing height, Atmos. Environ., 34, 1001-1027, doi:10.1016/S1352-2310(99)00349-0, 2000.

Skyllingstad, E., Samelson, R., Mahrt, L., and Barbour, P.: A numerical Modeling study of warm offshore flow over cool water, Mont. Weather Rev., 133, 345-361, doi:10.1175/MWR-2845.1, 2005.

Solomon, S., Garcia, R., and Ravishankara, A.: On the role of iodine in ozone depletion, J. Geophys. Res.-Atmos., 99, 20491-20499, doi:10.1029/94JD02028, 1994.

Sorensen, J.: Sensitivity of the DERMA long-range gaussian dispersion model to meteorological input and diffusion parameters, Atmos. Environ., 32, 4195-4206, doi:10.1016/S13522310(98)00178-2, 1998.
Stull, R.: An Introduction to Boundary Layer Meteorology, Kluwer Academic Publishers, Dordrecht, the Netherlands, 1988.

Sturges, W., Cota, G., and Buckley, P.: Bromoform emission from arctic ice algae, Nature, 358, 660-662, doi:10.1038/358660a0, 1992.

Tegtmeier, S., Krüger, K., Quack, B., Atlas, E. L., Pisso, I., Stohl, A., and Yang, X.: Emission and transport of bromocarbons: from the West Pacific ocean into the stratosphere, Atmos. Chem. Phys., 12, 10633-10648, doi:10.5194/acp-12-10633-2012, 2012.

Tegtmeier, S., Krüger, K., Quack, B., Atlas, E., Blake, D. R., Boenisch, H., Engel, A., Hepach, H., Hossaini, R., Navarro, M. A., Raimund, S., Sala, S., Shi, Q., and Ziska, F.: The contribution of oceanic methyl iodide to stratospheric iodine, Atmos. Chem. Phys. Discuss., 13, 11427-11471, doi:10.5194/acpd-13-114272013, 2013.

Troen, I., and Mahrt, L.: A simple-model of the atmospheric boundary-layer: Sensitivity to surface evaporation, Bound.-Lay. Meteorol., 37, 129-148, doi:10.1007/BF00122760, 1986.

Vickers, D., Mahrt, L., Sun, J., and Crawford, T.: Structure of offshore flow, Mon. Weather Rev., 129, 1251-1258, doi:10.1175/1520-0493(2001)129<1251:SOOF > 2.0.CO;2, 2001.

Vogelezang, D., and Holtslag, A.: Evaluation and model impacts of alternative boundary-layer height formulations, Bound.-Lay. Meteorol., 81, 245-269, doi:10.1007/BF02430331, 1996.

Warwick, N., Pyle, J., Carver, G., Yang, X., Savage, N., O'Connor, F., and Cox, R.: Global modeling of biogenic bromocarbons, J. Geophys. Res.-Atmos., 111, D244305, doi:10.1029/2006JD007264, 2006.

WMO: Definition of the thermal tropopause, WMO Bulletin, 136137, 1957.

WMO: Scientific Assessment of Ozone Depletion: 2006, Geneva, Switzerland, 572, 2007.

WMO: Scientific Assessment of Ozone Depletion: 2010, World Meteorological Organization, Geneva, 2011.

Yokouchi, Y., Hasebe, F., Fujiwara, M., Takashima, H., Shiotani, M., Nishi, N., Kanaya, Y., Hashimoto, S., Fraser, P., ToomSauntry, D., Mukai, H., and Nojiri, Y.: Correlations and emission ratios among bromoform, dibromochloromethane, and dibromomethane in the atmosphere, J. Geophys. Res.-Atmos., 110, D23309, doi:10.1029/2005JD006303, 2005.

Ziska, F., Quack, B., Abrahamsson, K., Archer, S. D., Atlas, E., Bell, T., Butler, J. H., Carpenter, L. J., Jones, C. E., Harris, N. R. P., Hepach, H., Heumann, K. G., Hughes, C., Kuss, J., Krüger, K., Liss, P., Moore, R. M., Orlikowska, A., Raimund, S., Reeves, C. E., Reifenhäuser, W., Robinson, A. D., Schall, C., Tanhua, T., Tegtmeier, S., Turner, S., Wang, L., Wallace, D., Williams, J., Yamamoto, H., Yvon-Lewis, S., and Yokouchi, Y.: Global sea-to-air flux climatology for bromoform, dibromomethane and methyl iodide, Atmos. Chem. Phys. Discuss., 13, 5601-5648, doi:10.5194/acpd-13-5601-2013, 2013. 